\title{
非定常三次元遷音速ガスタービン翼列流れの数值解析*
}

\author{
山本悟*1, 白 石

\section{Computation of Unsteady 3-D Transonic Flow through Gas Turbuine Cascade Channel}

隆*2

\author{
Satoru YAMAMOTO and Takashi SHIRAISHI
}

\begin{abstract}
Unsteady three-dimensional transonic viscous flows through a gas turbine cascade channel are numerically investigated using the higher-resolution shock-vortex capturing method proposed by the authors. The higher-resolution both in space discretization and time integration enables us to obtain real flow characteristics in the 3-D gas turbine cascade. As numerical results, calculated unsteady 3-D vortical structures in the wake and at the corner are shown, and obtained unsteady flow patterns near the blade under on-and off-design conditions are compared with eath other.
\end{abstract}

Key Words: Turbomachinery, CFD, Unsteady Flow, Transonic Flow, FDM

\section{1. 緒言}

ガスタービン翼列流れの研究は, 実験や数值解析に よりこれまでに数多く行われてきた。特に垔音速翼列 流れに関しては, 非定常三次元流れの詳細が実験(1)(2) や数值解析 ${ }^{(3)(4)}$ により明らかにされている。一方，今 後高性能なガスタービン開発のうえで重要視されるべ き遷音速翼列の三次元流れに関しては，既存のほとん どの研究では, いまだ時間平均化された赛験データも しくは定常解を得ているのが現状のようである。本来 翼列流れは，非定常でかつ三次元的であるといえる。 特に遷音速流れでは，衝撃波が発生し境界層と干渉し て極めて複雑な非定常流れになることが予想される. これらの研究がいまだ進展していない理由としては, まず実験による非定常三次元流れの計測には高度な技 術と膨大な費用が必要であること，一方数值解析にお いては, 衝撃波や渦を伴う非定常流の数值解法がいま だ開発途上であることなどが考えられる。非定常を仮 定した三次元遷音速翼列流れの数值解析もすでに試み

* 原稿受付 1997 年 5 月 6 日.

*1 正員, 東北大学大学院工学研究科 (画980-8579 仙台市青葉区 荒巻字青葉 01).

*2 東北大学大学院.
られてはいるが, 衝撃波と境界層との干涉による後流 渦や翼コーナ渦の非定常性がまったく再現されていな い(5).この原因は比較的明らかであり，用いている数 值解法の解像度がそれらの流れ現象を捕獲するのには 不十分だからである。上記の非定常流現象は，定性的 には実験によりその存在が報告されている(6). したが って，これら現象を再現できるような数値解法の開発 が必要である。

著者らは，遷音速翼列流れの非定常性に着目して， 上記非定常流現象を捕獲する目的で高解像差分スキー ムを開発した ${ }^{(7) \sim(9)}$ 。これは，空間方向最大四次精度， 時間方向最大二次精度を有した特性の理論に基づいた TVD 条件を満足する差分スキームである。すでに行 っている数値解析から, 衝撃波のみならず接触不連続 面や渦の捕獲に優れていることが示された(10). また， 非定常二次元遷音速翼列流れの数値解析では, 衝撃波 と境界層の干渉による翼後縁からの周期的な渦放出や 衝撃波の振動が鮮明に捕獲されている(11).

本研究の目的は，上記の高解像差分スキームをガス タービン翼列を通る非定常三次元遷音速流れに適用 し, 実験で報告されている翼後縁から発生する非定常 後流渦を数值解析により捕獲することであり, 重ねて その三次元渦構造を考察することである.さらに設 
計・非設計状態における翼コーナ渦の時間依存性につ いても考察する.

\section{おもな記 号}

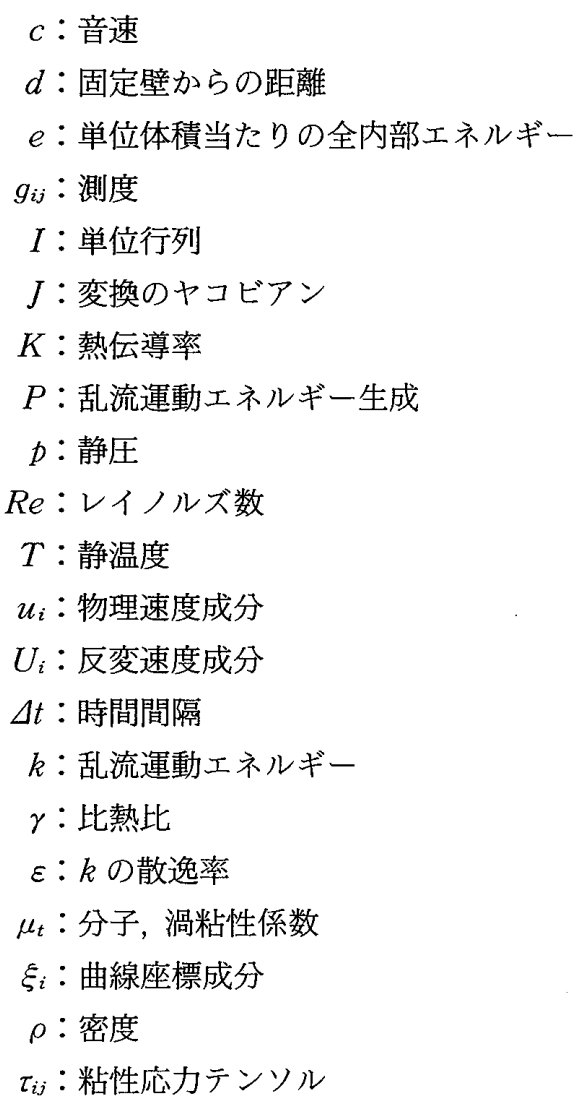

\section{2. 基礎方程式}

非定常三次元遷音速粘性流れの基䃈方程式として, 一般曲線座標系の三次元圧縮性ナビエ・ストークス方 程式ならびに乱流を考慮するため低レイノルズ数型二 方程式 $k-\varepsilon$ モデルを連立して解く。これらの方程式 はベクトル形で次のように記述される。

$$
\begin{aligned}
& \partial \hat{Q} / \partial t+\widehat{F}(\widehat{Q}) \\
& \quad=\frac{\partial \hat{Q}}{\partial t}+\frac{\partial \hat{F}_{i}}{\partial \xi_{i}}+\frac{1}{R e} \widehat{S}+\hat{H}=0 .
\end{aligned}
$$

ただし，

$$
\widehat{Q}=J\left[\begin{array}{c}
\rho \\
\rho u_{1} \\
\rho u_{2} \\
\rho u_{3} \\
e \\
\rho k \\
\rho \varepsilon
\end{array}\right], \quad \widehat{F}_{i}=J\left[\begin{array}{c}
\rho U_{i} \\
\rho u_{1} U_{i}+\partial \xi_{i} / \partial x_{1} p \\
\rho u_{2} U_{i}+\partial \xi_{i} / \partial x_{2} p \\
\rho u_{3} U_{i}+\partial \xi_{i} / \partial x_{3} p \\
(e+p) U_{i} \\
\rho k U_{i} \\
\rho \varepsilon U_{i}
\end{array}\right]
$$

$$
\hat{S}=-J \frac{\partial \xi_{i}}{\partial x_{j}} \frac{\partial}{\partial \xi_{i}}\left[\begin{array}{c}
0 \\
\tau_{1 j} \\
\tau_{2 j} \\
\tau_{3 j} \\
\tau_{k j} u_{k}+K \partial T / \partial x_{j} \\
\sigma_{k j} \\
\sigma_{\varepsilon j}
\end{array}\right],
$$$$
\widehat{H}=-J\left[\begin{array}{c}
0 \\
0 \\
0 \\
0 \\
0 \\
f_{k} \\
f_{\varepsilon}
\end{array}\right]
$$

$J$ は変換のヤコビアン, $U_{i}$ は反変速度成分, $\tau_{i j}$ は粘 性応力で次のように定義する。

$$
\begin{aligned}
& J=\partial\left(x_{1}, x_{2}, x_{3}\right) / \partial\left(\xi_{1}, \xi_{2}, \xi_{3}\right) \\
& U_{i}=\left(\partial \xi_{i} / \partial x_{j}\right) u_{j} \quad(i=1,2,3) \\
& \tau_{i j}=\left(\mu+\mu_{t}\right)\left[\left(\frac{\partial u_{i}}{\partial x_{j}}+\frac{\partial u_{j}}{\partial x_{i}}\right)-\frac{2}{3} \delta_{i j} \frac{\partial u_{k}}{\partial x_{k}}\right] \\
& -\frac{2}{3} \delta_{i j} \rho k R e \quad(i, j=1,2,3)
\end{aligned}
$$

圧力 $p$ は, 理想気体の状態方程式により定義される。

$$
p=\rho R T=(\gamma-1)\left[e-\rho u^{2} / 2\right]
$$

また, 乱流モデルの $k$ および $\varepsilon$ 方程式における拡散項 $\sigma_{k j}, \sigma_{\varepsilon j}$ とソース項の $f_{k}, f_{\varepsilon}$ はそれぞれ

$$
\begin{aligned}
& \sigma_{k j}=\left(\mu+\mu_{t} / C_{k}\right) \partial k / \partial \xi_{j} \\
& \sigma_{\varepsilon j}=\left(\mu+\mu_{t} / C_{\varepsilon}\right) \partial \varepsilon / \partial \xi_{j} \\
& f_{k}=\left(P-\rho \varepsilon R e-2 \mu k / d^{2}\right) / R e \\
& f_{\varepsilon}=\frac{k}{\varepsilon}\left(C_{1} f_{1} P-C_{2} f_{2} \rho \varepsilon R e-2 C_{3} \mu k / d^{2}\right) / R e
\end{aligned}
$$

ここで, 渦粘性係数 $\mu_{t}$ は

$$
\mu_{t}=R e \cdot C_{\mu} f_{\mu} \rho k^{2} / \varepsilon
$$

$C_{k}, C_{\varepsilon}, C_{1}, C_{2}, C_{3}, C_{\mu}$ は経験定数で, 本論文では Chien の低レイノルズ数型 $k-\varepsilon$ 方程式を用いる. 乱 流モデルの詳細については文献(12)に報告している.

\section{3. 数 值 解 法}

本研究で用いる高解像差分スキームを簡単に説明す れば次のようになる。

$3 \cdot 1$ 四次精度コンパクト MUSCL TVD (FCMT) スキーム 数值流束を構成する初期変数の高次補間 に, 著者らが提案した FCMT スキームを用いる。詳 細については文献 (7)にすでに報告しているのでここ では省略する，FCMT スキームの最大の利点は，ま 
ずその簡単さにあり, MUSCL ${ }^{(13)}$ をべースにした既存 のCFD コードがあれば, 本スキームの高次の項のみ からなるたかだか数行のサブルーチンを組み込めばよ い. ENO スキーム ${ }^{(14)}$ などの既存の差分スキームに比 ベ, 格段に簡単なアルゴリズムであり, 空間精度は従 来のたかだか三次精度の TVD スキーム(15)より高次 である。

$3 \cdot 2$ 流束差分離法 対流項の離散化に, Roe の 近似リーマン解法(16) に基づく流束差分離法を用いる。 本論文では, Roe 平均の計算アルゴリズムを考慮した 独自のサブベクトルを導出して数値流束を計算する. $\xi_{i}$ 座標方向の $l+1 / 2$ 点における数値流束 $\left(\hat{F}_{i}\right)_{l+1 / 2}$ は,

$$
\begin{aligned}
\left(\widehat{F}_{i}\right)_{l+1 / 2}= & \frac{1}{2}\left[\widehat{F}_{i}\left(\hat{Q}_{l+1 / 2}^{L}\right)+\widehat{F}_{i}\left(\widehat{Q}_{l+1 / 2}^{R}\right)\right. \\
& \left.-\left|\left(\hat{A}_{i}\right)_{l+1 / 2}\right|\left(\hat{Q}_{l+1 / 2}^{R}-\hat{Q}_{l+1 / 2}^{L}\right)\right]
\end{aligned}
$$

ここで， $Q^{L}, Q^{R}$ は，それぞれ FCMT スキームにより 上流を考慮して高次補間された未知変数べクトルを意 味する. $\left(\widehat{A}_{i}\right)_{l+1 / 2}$ は, 次式で計算される。

$$
\begin{aligned}
\left|\left(\hat{A}_{i}\right)\right|_{l+1 / 2} \hat{Q}^{L(R)}= & \left|\bar{\lambda}_{i 1}\right| \hat{Q}^{L(R)}+\frac{\left|\bar{\lambda}_{i a}\right|}{\bar{c} \sqrt{g_{i i}}} \bar{Q}_{i a} \\
& +\frac{\left|\bar{\lambda}_{i b}\right|}{\bar{c}^{2}} \bar{Q}_{i b} \ldots \ldots \ldots \ldots \ldots \ldots \ldots
\end{aligned}
$$

ただし，

$$
\begin{aligned}
& \lambda_{i 1}=U_{i}, \lambda_{i 4}=U_{i}+c \sqrt{g_{i i}}, \lambda_{i 5}=U_{i}-c \sqrt{g_{i i}} \\
& \left|\lambda_{i a}\right|=\frac{1}{2}\left(\left|\lambda_{i 4}\right|-\left|\lambda_{i 5}\right|\right) \\
& \left|\lambda_{i b}\right|=\frac{1}{2}\left(\left|\lambda_{i 4}\right|+\left|\lambda_{i 5}\right|\right)-\left|\lambda_{i 1}\right| \\
& \bar{Q}_{i a}=\bar{D} \bar{Q}_{i c}+\Delta \bar{m}_{i} \bar{Q}_{d}, \bar{Q}_{i b}=\Delta \bar{m}_{i} \bar{Q}_{i c}+\bar{p} \bar{Q}_{d} \\
& \bar{D}=\bar{Q}_{p} \cdot \bar{Q}^{M}, \Delta \bar{m}_{i}=\bar{Q}_{i m} \cdot \bar{Q}^{M}
\end{aligned}
$$$$
Q_{i c}=\left[\begin{array}{c}
0 \\
\partial \xi_{i} / \partial x_{1} \\
\partial \xi_{i} / \partial x_{2} \\
\partial \xi_{i} / \partial x_{3} \\
U_{i} \\
0 \\
0
\end{array}\right], Q_{d}=\left[\begin{array}{c}
1 \\
u_{1} \\
u_{2} \\
u_{3} \\
(e+p) / \rho \\
k \\
\varepsilon
\end{array}\right]
$$$$
Q_{p}=(\gamma-1)\left[\begin{array}{c}
u_{j} u_{j} / 2 \\
-u_{1} \\
-u_{2} \\
-u_{3} \\
1 \\
0 \\
0
\end{array}\right], Q_{i m}=\left[\begin{array}{c}
-U_{i} \\
\partial \xi_{i} / \partial x_{1} \\
\partial \xi_{i} / \partial x_{2} \\
\partial \xi_{i} / \partial x_{3} \\
0 \\
0 \\
0
\end{array}\right]
$$

ここでオーバラインは Roe 平均を意味する。

$$
3 \cdot 3 \text { 陰的近似因子化法 本研究では, 陰的時間 }
$$

進行法に基づく時間積分スキームを用いる，近似因子 化, 対角化, ならびに上流化が施されて導出された定 常計算のための対角化近似因子化法を，さらにニュー トン反復法とクランク・ニコルソン法を組み込むこと で，時間最大二次精度に拡張する。ただし，ここで用 いられる非保存形の固有べクトルからなる行列と非保 存形への変換行列は，反変速度を未知変数にもつ基礎 方程式に基づくものである。基礎方程式 (1)は, 変換 の行列 $B に よ り 反$ 変速度を末知変数にもつ基礎方程 式に変換される(17).すなわち

$$
B[\partial \hat{Q} / \partial t+\widehat{\mathscr{F}}(\widehat{Q})] \equiv \partial \widetilde{Q} / \partial t+\widetilde{\mathscr{F}}(\widetilde{Q})
$$

最終的に, 時間方向最大二次精度の陰的対角化近似因 子化法を式(13)に適用すると，

$$
\begin{aligned}
& \left\{\widetilde{S}_{1}^{-1}\left[I+\Delta t\left(\Lambda_{1}^{+} \nabla_{1}+\Lambda_{1}^{-} \Delta_{1}\right)\right]\right. \\
& \times \tilde{M}_{1}^{-1}\left[I+\Delta t\left(\Lambda_{2}^{+} \nabla_{2}+\Lambda_{2}^{-} \Delta_{2}\right)\right] \\
& \left.\times \widetilde{M}_{2}^{-1}\left[I+\Delta t\left(\Lambda_{3}^{+} \nabla_{3}+\Lambda_{3}^{-} \Delta_{3}\right)\right] \widetilde{S}_{3}\right\}^{m} \Delta \widetilde{Q}^{m} \\
& =R H S^{m}
\end{aligned}
$$

ただし，

$$
\begin{aligned}
\Delta \widetilde{Q}^{m}= & \widetilde{Q}^{m+1}-\widetilde{Q}^{m} \\
R H S^{m}= & -\left(\widetilde{Q}^{m}-\widetilde{Q}^{n}\right)-\Delta t B\left\{\widehat{F}^{*}\left(\widehat{Q}^{m}\right)\right. \\
& \left.+\widehat{F}^{*}\left(\widehat{Q}^{n}\right)\right\} / 2
\end{aligned}
$$

$\Lambda_{i}^{ \pm}$は $\lambda_{i j}^{ \pm}=\left(\lambda_{i j} \pm\left|\lambda_{i j}\right|\right) / 2$ 加らなる対角行列, $\widetilde{S}_{i}$ は, 固 有ベクトルからなる行列, $\tilde{M}_{1}=\widetilde{S}_{2} \widetilde{S}_{1}^{-1}, \tilde{M}_{2}=\widetilde{S}_{3} \widetilde{S}_{2}^{-1}$, $\nabla_{i}, \Delta_{i}$ は後退または前進差分演算子, $n$ は時間ステッ プそして $m$ はニュートン反復回数である。*は高解像 差分スキームで計算することを意味する。

\section{4. 数 值 計 算 例}

文献 ( 6 )のガスタービン翼列翼形状を基にした線形 静翼列の三次元非定常遷音速流れを, 入口流入角を変 化させて数值解析した. 計算条件は, 入口全温 $290 \mathrm{~K}$, 入口全圧 $0.964 \times 10^{5} \mathrm{~Pa}$, 出口等エントロピーマッハ 数 0.99 , レイノルズ数 $8.5 \times 10^{5}$, 翼ピッチ 0.71 , 翼ア スペクト比 0.5 とし, 入口流入角は $30^{\circ}$ (設計状 態)，－30, $60^{\circ}$ (非設計状態)を選択した。この場合, 非設計状態は必ずしも実際の条件を想定したものでは なく，本数值解法の頑丈さを示すとともに翼正圧面な らびに負圧面にはく離が起きると予想される入口流入 角を設定している。図 1 に計算格子の概略図を示す. 格子点数は $\xi \eta \zeta$ 方向それぞれ $181 \times 61 \times 41$. 初期值は 一樣流を与え, 入口には乱流境界層を仮定して $1 / 7$ 乗 則に基づく速度分布を与える. 最初の 1000 反復は, ニュートン反復なしで計算し, その後はニュートン反 復を 3 回行って非定常計算した。

まず，入口流入角 $30^{\circ}$ の設計状態における計算結果 について説明する，図 2 に計算により得られた瞬間等 


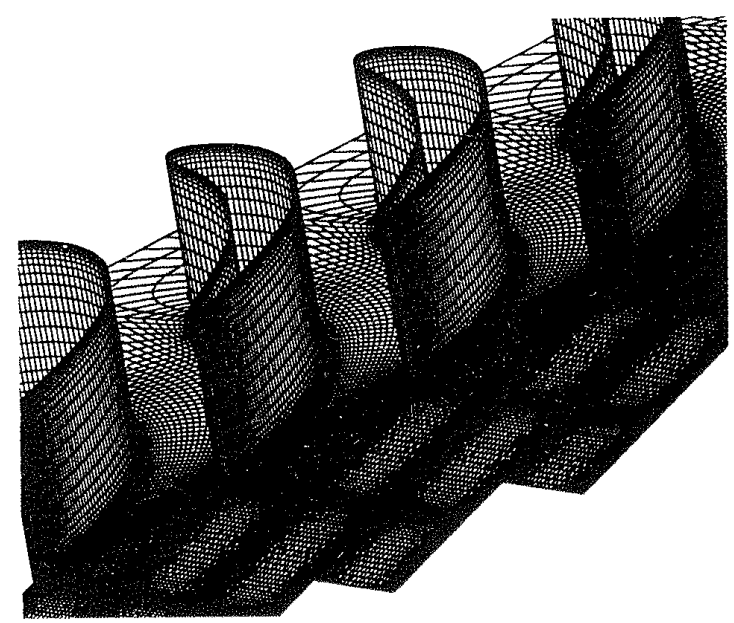

Fig. 1 Computational grid

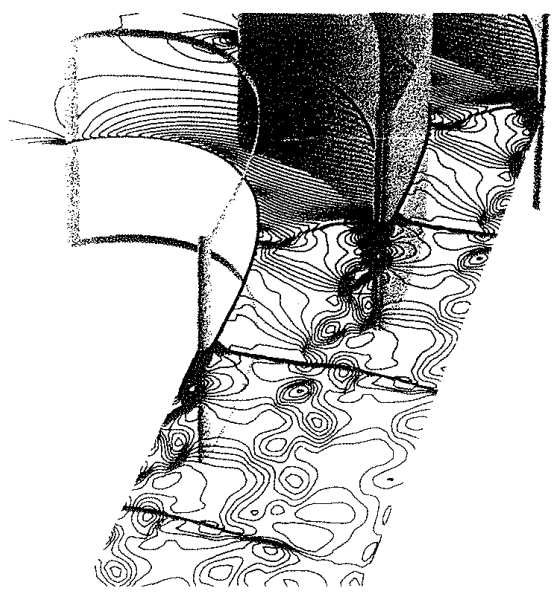

Fig. 2 Instantaneous Mach number contours (3D)

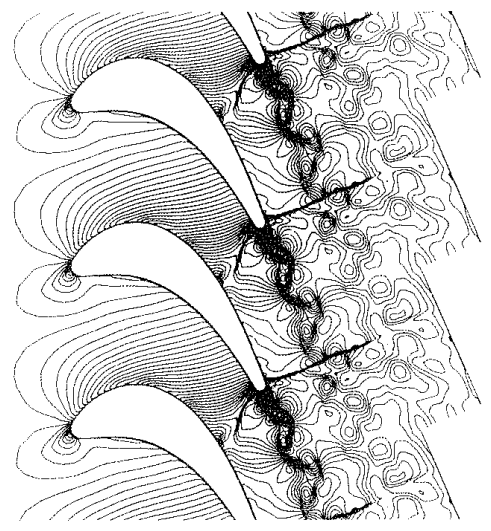

Fig. 3 Instantaneous Mach number contours (2D)

マッ八数分布を示す。また, 図 3 には二次元の場合の 計算結果を示す。両者いずれも, 翼後縁で発生してい る垂直衝撃波が鮮明に捕獲されている.さらに, 翼後 縁からの後流渦も, その発生の周期と後流の幅につい てほとんど同様の結果が得られた。

図 4 には, 50\%スパンにおける異なった時間におけ る翼表面瞬間等エントロピーマッハ数分布 (3D

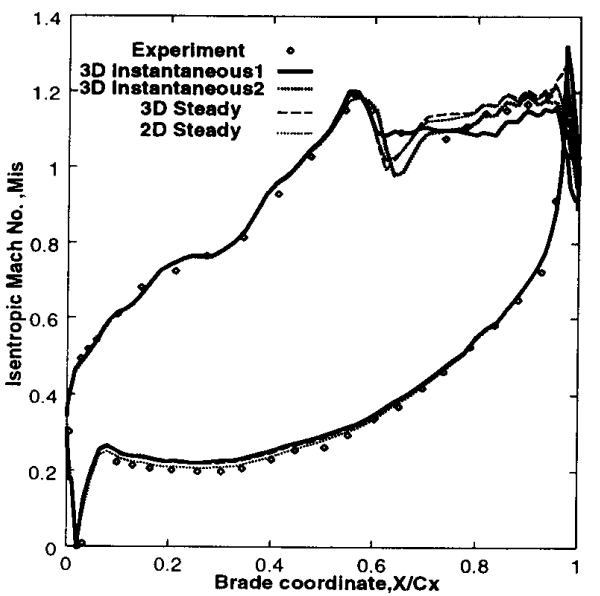

Fig. 4 Isentropic Mach number distributions

Instantaneous 1,2) を, 二次元定常計算 (2 D Steady), 三次元定常計算 (3 D Steady) ならびに実験結果と比較 する，本計算結果は，衝撃波が発生している翼負圧面 後縁付近を除いてはいずれも他の結果とよく一致して おり実験条件をよく再現していることがわかる。

図 5(a)，(b)は，翼後流域の計算格子に沿った流 路断面での異なった時間における瞬間速度べクトル分 布を示す。ただし，それぞれ，50\%スパンにおける速 度べクトル変動の位相が $180^{\circ}$ 異なる場合 $\left(\theta=\theta_{0}, \theta_{0}\right.$ $+\pi)$ を示した. この断面では, 翼後流渦に伴う速度べ クトルの方向が周期的に変動していることがわかっ た.さらに, Endwall 付近においても異なった速度べ クトル分布が示されており，コーナー渦と後流渦が干 涉していることが示唆される。

図 6 には, 翼後流渦の三次元構造を考察するために, 後流渦の渦系構造を瞬間等渦度分布を表示することに より可視化した，翼列翼後縁から下流方向に, 交互に 渦系構造をもった渦が放出されて渦列を形成している が，スパン方向に湾曲した分布をもっているのが示さ れており, Endwall の境界層を除き, 渦系の中心位置 は Endwall 方向ほど下流に位置している。これは翼 後流渦が対流速度の速い翼コーナー渦と干渉している ためであると考えられる。

次に，翼コーナー渦の非定常性を調べるために異な つた時間での翼負圧面と正圧面における瞬間限界流線 を図7,8に示す.これらには翼負圧面においてコー ナー渦が発生している様子が示されているが, 計算結 果には本設計状態における翼負圧面と正圧面での時間 による変化はほとんど示されなかった。

次に非設計状態における翼コーナー渦の非定常性に ついて検討した，紙面の都合上, 瞬間限界流線のみを 示す. 図 9,10 に入口流入角一 $30^{\circ}$ にお る翼負圧面 


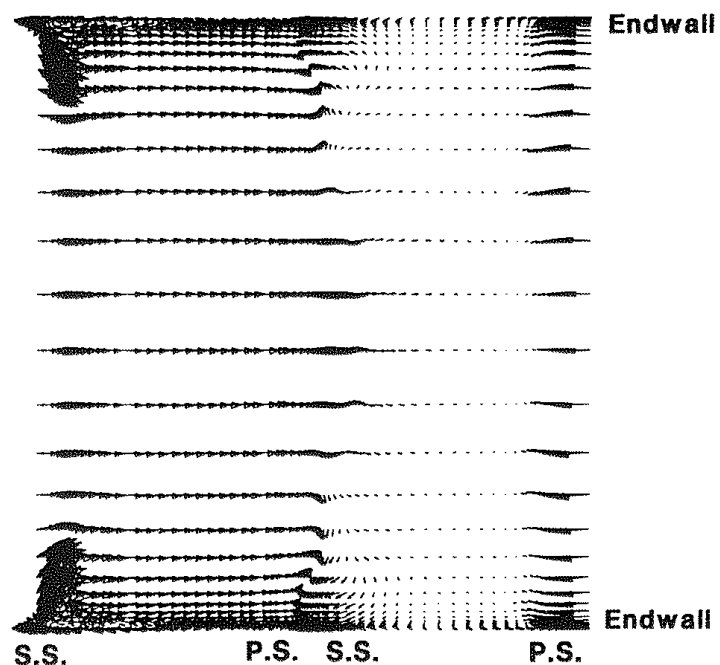

(a) $\theta=\theta_{0}$

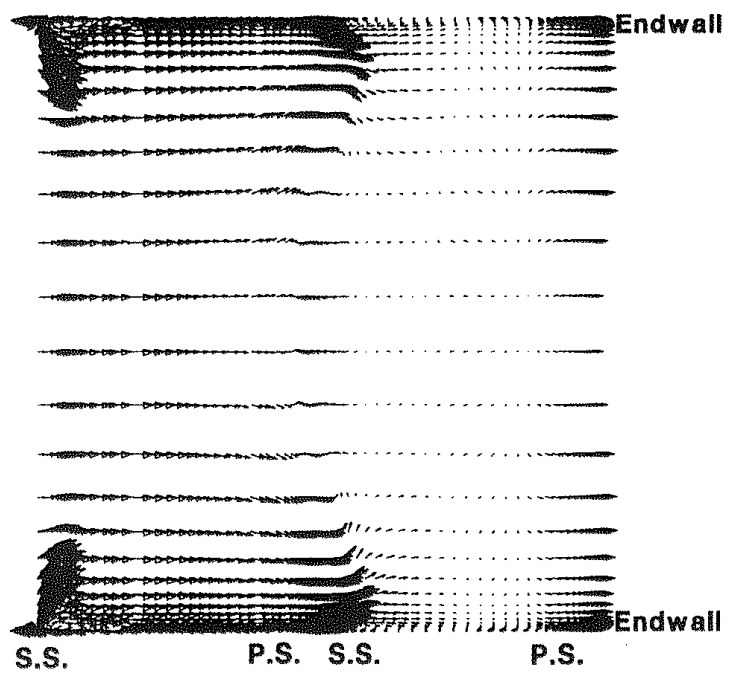

(b) $\theta=\theta_{0}+\pi$

Fig. 5 Instantaneous velocity vectors

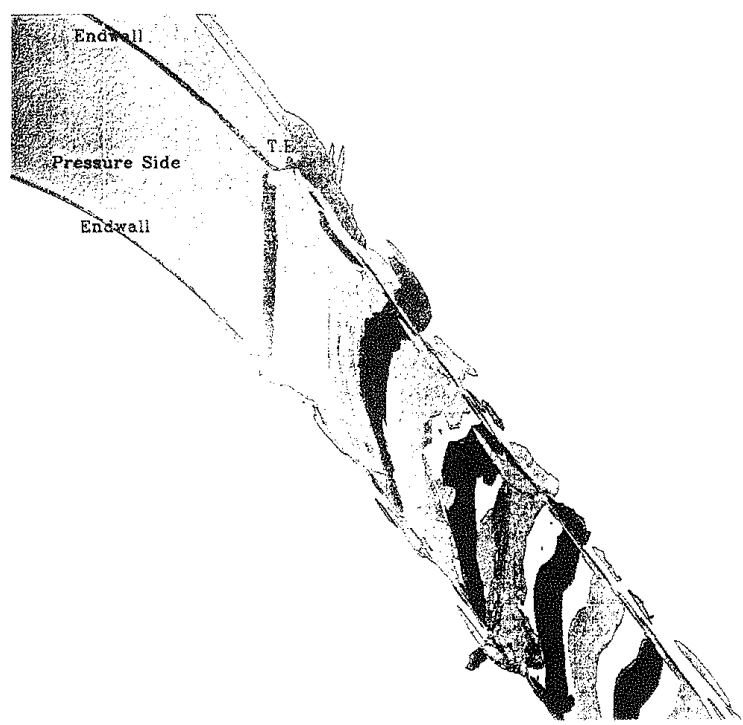

Fig. 6 Instantaneous vorticity contours

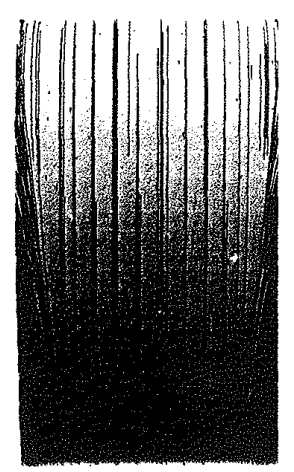

(a) $t=t_{0}$

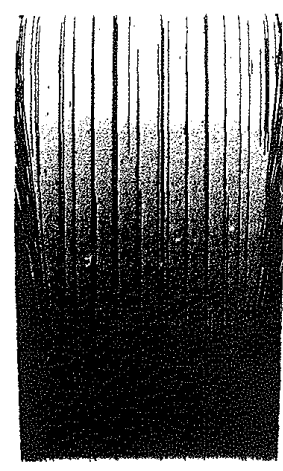

(b) $t=t_{0}+\Delta t$
Fig. 7 Instantaneous limiting streamline (suction side)

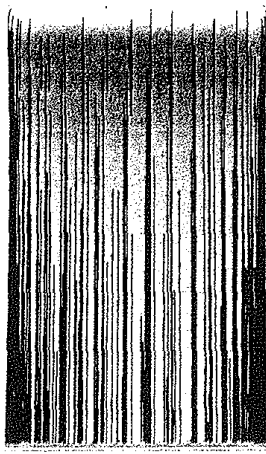

(a) $t=t_{0}$

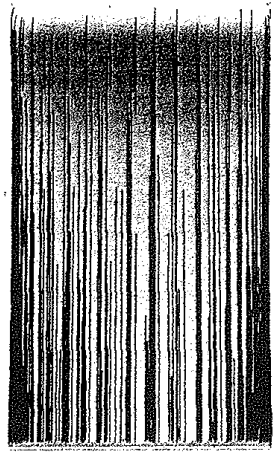

(b) $t=t_{0}+\Delta t$
Fig. 8 Instantaneous limiting streamline (pressure side)

と正圧面での瞬間限界流線, 図 11,12 に入口流入角 $60^{\circ}$ における同様の分布を示す。まず，前者の条件で は翼圧力面で大規模なはく離が生じることを二次元計 算 ${ }^{(18)}$ ならびに本計算で確認しているが, 図 10 の正圧 面にはそのはく離の影響を見いだすことができる．翼 面前半付近に大規模渦の再付着点があり，付着後は翼 面中央へ流れが集まっている様子が示されている。一 方, 入口流入角 $60^{\circ}$ の場合は, 翼負圧面の翼コーナー 渦が時間に依存している様子が翼前緑コーナー付近の 変動により示されている。これは大きな流入角を設定 したことにより翼負圧面前縁近傍で流れがはく離して いることが原因であると考えられる。

ところで，これら非定常計算結果と定常計算結果を 比較するために, 入口流入角一 $30^{\circ}$ における翼正圧面 ならびに入口流入角 $60^{\circ}$ における翼負圧面での限界流 線をそれぞれ図 13(a)，（b）に示す。これらを非定常 計算の結果と比較すれば, 特に図 13(a)の分布は図 10 のものとはまったく異なった分布を示しており，入 口流入角がー $30^{\circ}$ のような翼圧力面側に大きなはく離 を伴うような場合においては, 定常計算の信頼性にか なり問題があることが示唆される。しかしながら，実 験結果と比較しているわけではないので，今後のさら 


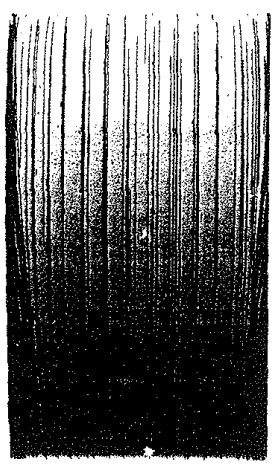

(a) $t=t_{1}$

Fig. 9 Instantaneous limiting streambine (suction side, $-30^{\prime \prime}$ )
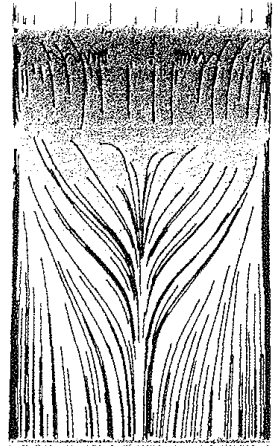

(a) $1=-1$,

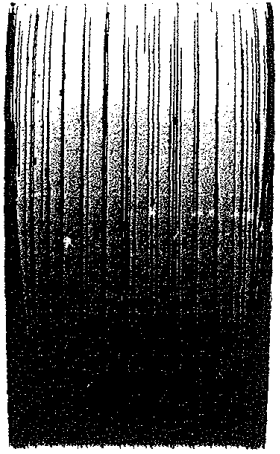

(b) $t=t_{1}+\Delta t$

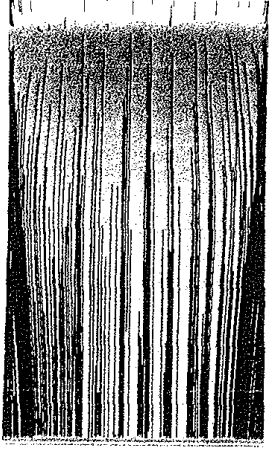

(a) $1=12$

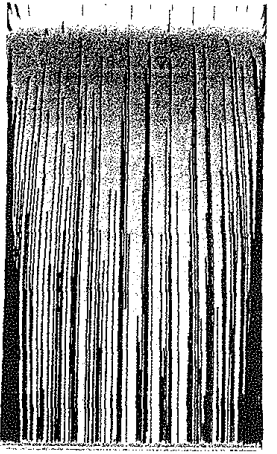

(b) $t=t_{2}+\Delta t$
Fig. 12 Instantaneous limiting streamline (pressure side, $60^{\circ}$ )

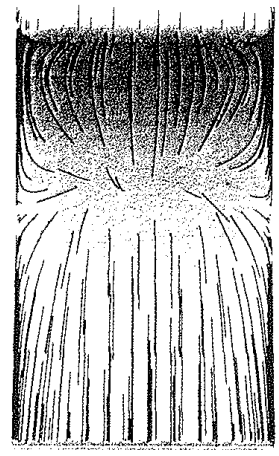

(a)

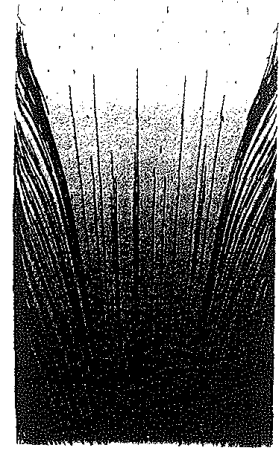

(b)
Fig. 13 Limiting streamiline (steady state solution)

期的に発生する点，ならびに非定常性の強い大規模渦 や翼コーナー渦が翼面付近に発生する点が, 本数值解 析においても再現された。

（2）さらに, 翼後流域では翼後流渦と翼コーナー 渦とが干涉して, 翼後流渦自体が複雑な三次元的構造 に変化しているという計算結果が得られた。

（2）については実験に扔いてもいまだよく知られて いないものであるが，ガスタービン翼列の高性能化に 伴う翼冷却法(19) とも関連して, 今後その詳細な解明 の必要性が示唆される。

\section{文献}

(1) Heinemann, H. J., ほか 2 名, Proceeding IUTAM Sym posium Trans-sonicum, II (1976), 75, Springer-Verlag.

(2) Yamamoto, A., Trans. ASME, J. Turbomach., 109 (1987), 186-193.

(3) Rai, M. M., AIAA Paper, 87-2058, (1987).

(4) Hah, C., AIAA Paper, 92-3211 (1992).

(5) Dawes, W. N., ASME Paper, 90-GT-18(1990).

(6) Kiock, R., ほか, Trans. ASME, J. Eng. Gas Turbine Power, 108(1986), 277-285.

(7) Yamamoto, S. and Daiguji, H., Comput. Fluids, 22 (1993), 259-270.

(8) Yamamoto, S. and Daiguji, H., AIAA Paper, 92-

た衝撃波と境界層が干渉することにより後流渦が周 
3044 (1992).

(9) Yuan, X., ほか2 名, AIAA Paper, 94-3199(1994).

(10) Yamamoto, S., ほか2名, H., AIAA Paper, 94-2305 (1994)

(11) Tanuma, T., 淰か3名, Unsteady Aerodynamics and Aeroelasticity of Turbomachines, (1995), 691-707, Elsevier Science.

(12) Yamamoto, S. and Daiguji, H., JSME Int., 37-3(1994), $522-530$.
(13) Anderson, W. K., 仿加 2 名, AIAA J., 24-9(1986), 1453.

(14) Harten, A., J. Comput. Phys., 83(1989), 148-184.

(15) Yee, H. C., J. Comput. Phys., 68(1987), 151-179.

(16) Roe, P. L., J. Comput. Phys., 43(1981), 357-372.

(17）山本悟・ほか 2 名, 機論, 56-523, B(1990), 765-772.

(18) Yamamoto, S., ほか2 名, Proc. 1995 Yokohama Int. Gas. Turbine Congr., I(1995), 27-34.

(19) Friedrichs, S., ほか 2 名, Trans. ASME, J. Turbomach., 119 (1997), 786-793. 